\title{
Religious Social Values in the Wiridan Tradition in the Village of Lubuk Bayas, North Sumatra
}

\author{
Mutaqin Alzamzami \\ Fakultas Ushuluddin dan Pemikiran Islam, Universitas Islam Negeri \\ Sunan Kalijaga, Yogyakarta, Indonesia \\ email: muttaqinalzamzami86@gmail.com \\ Sholahuddin Ashani \\ Fakultas Ushuluddin dan Studi Islam, Universitas Islam Negeri \\ Sumatera Utara, Indonesia \\ email: sholahuddinashani@uinsu.ac.id \\ Rizki Ade Syahputra \\ Ilmu Hadis Fakultas Ushuluddin, Al-Azhar University, Egypt \\ email: adesyahputrarizki@gmail.com
}

\begin{abstract}
This article describes the wiriddan tradition carried out by the community in Lubuk Bayas Village, North Sumatra. The focus of this study is on two wiriddan traditions, which take place twice a week, once especially for male congregations and another day specifically for female congregations. This research uses interview, observation, and descriptive analysis methods. In this tradition, the congregation usually reads surah yasin, al-ikhlash, al-falaq, al-nas and takhtim takhlil. Wiriddan activities take place at the house of a community by applying a rotating system. Through the interview method, the writer can classify several social values that are considered by the community to be very important and make it a motivation to continue to carry out the wiriddan tradition. The socio-religious values that are felt by the community, including the moment of gathering, the
\end{abstract}

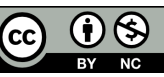

DOI: $10.19105 /$ karsa.v29i1.2345 
opportunity to give alms, mutual assistance, respect for teachers, a forum for dialogue between residents, and through this way, they can strengthen brotherhood, especially between neighbors.

[Artikel ini mendeskripsikan tradisi wiriddan yang dilakukan masyarakat di Desa Lubuk Bayas, Sumatera Utara. Fokus kajian ini yaitu pada dua tradisi wiriddan yang berlangsung dalam seminggu dua kali, sekali terkhusus bagi jemaah laki-laki dan seharinya lagi dikhususkan bagi jemaah perempuan. Penelitian ini menggunakan metode wawancara, observasi dan deskriptif-analisis. Jemaah dalam tradisi tersebut biasanya melaksanakan pembacaan surat yasin, surat al-ikhlash, al-falaq, al-nas dan takhtim takhlil. Kegiatan wiriddan berlangsung di rumah salah seorang masyarakat, dengan menerapkan sistem gilir. Penulis melalui metode wawancara dapat mengklasifikasikan beberapa nilai-nilai sosial yang dianggap oleh masyarakat sangat penting dan menjadikannya sebagai motivasi untuk terus melestarikan tradisi tersebut. Nilai-nilai sosial keagamaan yang dirasakan masyarakat, antara lain momen silaturahmi, kesempatan bersedekah, saling tolong-menolong, penghormatan terhadap guru, wadah untuk berdialog antar warga, dan melalui hal tersebut dapat mempererat tali persaudaraan terutama antar tetangga.]

Keywords: wiriddan tradition; fadilah; social values

\section{Introduction}

The Islamic culture that comes to Indonesia will influence the belief system and the behavior of the people in influencing the belief system (especially the Serdang Bedagai people) so that it can be seen in their religious experiences which are puritanical and syncretic. ${ }^{1}$ Talking about the origin of a regional tradition cannot be separated from talking about the heritage of the region itself, as well as the wiriddan tradition, which is still rooted in the hearts and beliefs of some North Sumatra people (especially in Lubuk Bayas village, Serdang Bedagai).

The wiriddan tradition is often carried out by the people of Lubuk Bayas village is the same as its predecessor society, by carrying out a reading every Friday night after completing the maghrib prayer in one of the community houses, which is rotated based on the previous

\footnotetext{
${ }^{1}$ Soeryono Soekanto, Sosiologi Suatu Pengantar (Jakarta : Rajawali Press, 1989), 172.
}

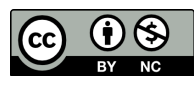

DOI: 10.19105/karsa.v29i1.2345 
agreement. This wiriddan tradition in Lubuk Bayas village is performed at night after maghrib prayer. According to residents, this event was carried out in order to get the glory and blessings of the Friday night, in which this tradition has been preserved from one generation to another. In addition, just spending a little time on that night can create harmony between the people of Lubuk Bayas Village, Serdang Bedagai Regency.

More uniquely, according to the author's opinion, the wiriddan tradition in Lubuk Bayas Village occurs in two stages in a week, namely the first wiriddan specifically for men and the second wiriddan specifically for women. For women, especially mothers, wiriddan is performed during the day after Friday prayers. So, this tradition is not only intended for men but there is a kind of time division in carrying out this tradition that has been passed down from generation to generation, namely at night, it is reserved for men only, while during the day it is reserved for women.

As for other events, for example, at a wedding. Before the bridegroom comes to the bride's house, the verses of the Koran (AlQur'an) are read first; in this case, one of the letters read is surah Yasin who is read in the house of the bride accompanied by the recitation of prayers for the two. Hopefully, the brides will be able to navigate the ark of their household in the future with sakinah, mawaddah, and mercy, more precisely so as not to experience failure in the household (divorce). ${ }^{2}$ In this study, the focal point is the socio-religious values that exist in the wirid tradition and what motivates the community to continue to organize the wiriddan tradition in Lubuk Bayas Village.

\footnotetext{
${ }^{2}$ In the bride's house, a sheet that has been covered with a neat cloth is provided, and a table or table is provided as a place for the al-Qur'an to be read by the prospective bride and groom. The bride-to-be begins to read short verses of the Koran, which are the main event in a series of Khataman al-Qur'an events. The short verses referred to are surah ad-Duha to al-Ikhlas. Sometimes those who read the Koran (short verses) are invited guests who are led directly by the bride's reciting teacher. The short verses read in turn until they finish. When the public reads these verses, the task of the prospective bride is to listen to the reading by pointing to the letters that the invited guests are reading with a stick as an indexing device.
}

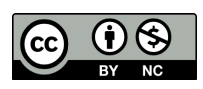

DOI: $10.19105 /$ karsa.v29i1.2345 


\section{Methods}

This research is a type of qualitative research, while the methods used are interview, observation, and descriptive-analysis methods in order to find out how the wiriddan traditions are carried out by the people of Lubuk Bayas village. This method was chosen to describe a situation related to the theme of the study, namely around the wiriddan tradition, by explaining the meaning and elements of religion in the tradition, then analyzing the religious elements by taking into account the values of preaching and the religious motivation of the community in preserving these traditions.

In terms of the wiriddan tradition, the writer sees that the form of religious tradition practice grows and develops in the community, not only in Lubuk Bayas Village but in the surrounding villages, even in most villages in Serdang Bedagai Regency that still preserves this culture. However, this research only focuses on locations in Lubuk Bayas Village, Perbaungan District, Serdang Bedagai Regency, North Sumatra Province. The wiriddan tradition only invites local people from family and neighbors. In this activity, people who are invited to the wiriddan (male congregation) event are usually delivered food in the afternoon before the event is held.

In data collection, interviews are needed so that the data can be collected easily. The researchers used the informants' or resource persons' spare time to conduct interviews with several people in Lubuk Bayas Village, including Mr. H. Hasan Siregar (representing parents), then male congregations. Males like Mr. Fauzi, Dahlan Siregar, Andi, and Syahrial, interviews were also conducted with one of the female congregations, namely Mrs. Rina as an active community of women and girls, then finally to one of the youth representatives of Nurul Iman mosque, Lubuk Bayas Village, namely a sister Leny. With this interview method, it is hoped that the sources can help provide the information needed to complete this study. The reason for this research was conducted in Lubuk Bayas Village, Perbaungan District, in Serdang Bedagai Regency by introducing the Islamic traditions that developed in Lubuk Bayas Village. After the data from the interviews, the observations were collected, and the data were analyzed using

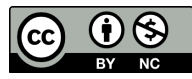

DOI: $10.19105 /$ karsa.v29i1.2345 
descriptive-analytical methods in order to present the data in order to draw conclusions.

\section{Results}

\section{Geographical Description of the Research Area}

Serdang Bedagai Regency is one of the 24 other districts in North Sumatra Province; apart from 25 districts, North Sumatra Province also has eight cities. The total area of Serdang Bedagai Regency is 1900,22 $\mathrm{km}^{2}$. At North of Serdang Bedagai Regency borders on Malaka Strait, at South it borders on Simalungun Regency, at East, it borders on Batu Bara and Simalungun Regency, and at West, it borders on Deli Serdang Regency. Serdang Bedagai Regency is one of the regencies located on the East Coast of North Sumatera. Geographically, Serdang Bedagai Regency is located at $3^{\circ} 01^{\prime} 2,5^{\prime \prime}$ North latitude until $3^{\circ} 46^{\prime} 33^{\prime \prime}$ North latitude, 98 $44^{\prime} 22^{\prime \prime}$ East longitude until 99 $19^{\prime} 01^{\prime \prime}$ East longitude, so it makes Serdang Bedagai as one of the East coast regencies in Sumatera Utara Province. It lies 0-500 m above sea level. ${ }^{3}$

The Administration of Serdang Bedagai Regency was divided into 17 districts, while 17 Districts and their area can be seen in the following table: ${ }^{4}$

\begin{tabular}{|l|l|l|l|}
\hline No & Subdistrict & $\begin{array}{l}\text { Capital of } \\
\text { Subdistrict }\end{array}$ & $\begin{array}{l}\text { Total Area } \\
\text { (square } \mathbf{k m} \text { ) }\end{array}$ \\
\hline 01 & Kotarih & Kotarih & 78,02 \\
\hline 02 & Silinda & Silinda & 56,75 \\
\hline 03 & Bintang Bayu & Bintang Bayu & 95,59 \\
\hline 04 & Dolok Masihul & Dolok Masihul & 237,42 \\
\hline 05 & Serbajadi & Serbajadi & 50,69 \\
\hline 06 & Sipispis & Sipispis & 145,26 \\
\hline 07 & Dolok Merawan & Dolok Merawan & 120,66 \\
\hline 08 & Tebing Tinggi & Tebing Tinggi & 182,29 \\
\hline
\end{tabular}

${ }^{3}$ BPS-Statistics of Serdang Bedagai Regency, Serdang Bedagai Regency in Figures 2020 (Serdang Bedagai: BPS Kabupaten Serdang Bedagai, 2020), 3.

${ }^{4}$ BPS-Statistics, Serdang Bedagai Regency in Figures 2020, 6.

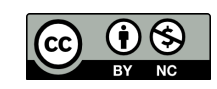

DOI: $10.19105 /$ karsa.v29i1.2345 


\begin{tabular}{|l|l|l|l|}
\hline 09 & $\begin{array}{l}\text { Tebing } \\
\text { Syahbandar }\end{array}$ & Paya Pasir & 120,60 \\
\hline 10 & Bandar Khalipah & Bandar Khalipah & 116,00 \\
\hline 11 & Tanjung Beringin & Tanjung Beringin & 74,17 \\
\hline 12 & Sei Rampah & Sei Rampah & 198,90 \\
\hline 13 & Sei Bamban & Sei Bamban & 72,26 \\
\hline 14 & Teluk Mengkudu & Sialang Buah & 66,95 \\
\hline 15 & Perbaungan & Perbaungan & 111,62 \\
\hline 16 & Pegajahan & Pegajahan & 93,12 \\
\hline 17 & Pantai Cermin & Pantai Cermin & 80,30 \\
\hline & Serdang Bedagai & Sei Rampah & $\mathbf{1 9 0 0 , 2 2}$ \\
\hline
\end{tabular}

\section{(Source: Part of Government and Cooperation Serdang Bedagai Regency)}

Perbaungan district, in terms of area, has an area of $111,62 \mathrm{Km}^{2}$, is located in position $3^{\circ} 35^{\prime} 24,6408^{\prime \prime}$ North Latitude - $98^{\circ} 55^{\prime} 57,2556^{\prime \prime}$ East Longitude, with altitudes ranging from 0-65 meters above sea level. Perbaungan sub-district is directly adjacent to Pantai Cermin District in the north, in the South it is bordered by Pegajahan sub-district, East by Teluk Mengkudu District, and West by Pagar Merbau District, Deli Serdang Regency. Perbaungan sub-district has a total of 28 villages/wards and consists of 112/24 hamlets/neighborhoods. When displayed specifically, the area of each village in Serdang Bedagai District can be seen in the following table: ${ }^{5}$

\begin{tabular}{|c|c|c|c|}
\hline No & Village/Subdistrict & $\begin{array}{l}\text { Total Area } \\
\text { (square km) }\end{array}$ & Percentage \\
\hline 01 & Adolina & 16,74 & 14,997 \\
\hline 02 & Melati II & 11,80 & 10,572 \\
\hline 03 & Tanjung Buluh & 7,39 & 6,621 \\
\hline 04 & Sei Buluh & 1,23 & 1,102 \\
\hline
\end{tabular}

\footnotetext{
${ }^{5}$ BPS-Statistics of Serdang Bedagai Regency, Kecamatan Perbaungan dalam Angka 2019 (Deli Serdang: BPS Kabupaten Deli Serdang, 2019), 5-6.
}

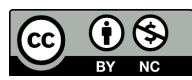

DOI: $10.19105 /$ karsa.v29i1.2345 


\begin{tabular}{|c|c|c|c|}
\hline 05 & Sei Jenggi & 2,71 & 2,428 \\
\hline 06 & Deli Muda Hulu & 3,77 & 3,378 \\
\hline 07 & Melati I & 1,17 & 1,102 \\
\hline 08 & Citaman Jernih & 1,62 & 1,451 \\
\hline 09 & Batang Terap & 1,97 & 1,765 \\
\hline 10 & Simpang Tiga Pekan & 1,78 & 1,595 \\
\hline 11 & Kota Galuh & 3,00 & 2,688 \\
\hline 12 & Tualang & 3,04 & 4,515 \\
\hline 13 & Bengkel & 1,37 & 1,227 \\
\hline 14 & Deli Muda Hilir & 4,63 & 4,148 \\
\hline 15 & Tanah Merah & 3,39 & 3,037 \\
\hline 16 & Lubuk Bayas & 4,81 & 4,309 \\
\hline 17 & Sei Naga Lawan & 5,58 & 4,999 \\
\hline 18 & Lubuk Rotan & 3,64 & 3,261 \\
\hline 19 & Kesatuan & 3,32 & 2,974 \\
\hline 20 & Lidah Tanah & 4,60 & 4,121 \\
\hline 21 & Pematang Tatal & 1,89 & 1,693 \\
\hline 22 & Lubuk Dendang & 1,76 & 1,577 \\
\hline 23 & Suka Beras & 3,26 & 2,921 \\
\hline 24 & Cinta Air & 3,52 & 3,154 \\
\hline 25 & Pematang Sijonam & 4,71 & 4,220 \\
\hline 26 & Lubuk Cemara & 2,50 & 2,240 \\
\hline 27 & Jambur Pulau & 2,47 & 2,213 \\
\hline \multirow[t]{2}{*}{28} & Suka Jadi & 1,95 & 1,747 \\
\hline & Perbaungan & 116,62 & 100,000 \\
\hline
\end{tabular}

(Source: Village / Subdistrict Office of Perbaungan District)

Lubuk Bayas Village consists of 4 hamlets, in which there are two kindergartens and has 1 Elementary Schools with 14 teaching staff, and also has 1 Islamic Elementary School and 1 Islamic Junior High School. As for the number of places of worship in Lubuk Bayas Village, namely 3 mosques, 6 Mushollahs, 0 churches, 0 temples, 0 monasteries, it can be ascertained that the majority of the population in Lubuk Bayas

\section{(c) $\underset{\mathrm{BY}}{\mathrm{B}(\mathrm{ic})}$}

DOI: $10.19105 /$ karsa.v29i1.2345 
Village are Muslims, and as many as 57 people sent for Hajj pilgrims in 2018, and this research coincides in the village of Lubuk Bayas.

\section{Definition of the Koran (Al-Qur'an)}

The Qur'an is a form masdhar of the verb Qara'a, which means "reading" of the holy book that was revealed to the Prophet Muhammad. ${ }^{6}$ Taufik Adnan Amal defines the Koran as the holy book of the Muslims, which contains a collection of divine revelations that were sent down to the Prophet Muhammad for approximately 23 years, popularly referred to as the Koran. ${ }^{7}$

The word al-Qur'an is isim mashdar (noun) of the word (قرأ) with meaning isim maf'ul, so it means "reading". ${ }^{8}$ Meanwhile, according to Nur Efendi and Muhammad Fathurrohman in their work "Study alQur'an: Memahami Wahyu Allah Secara Lebih Integral dan Komprehensif" defines al-Qur'an with the miraculous word of Allah that was revealed to the Prophet Muhammad in accordance with its editorial through the angel Gabriel, gradually, which are written in the mushaf-mushaf and valuable worship for those who read it, which begins with surah al-fatihah and ends with surah al-nas. ${ }^{9}$

According to one of the Indonesian interpreter or commentator, Quraish Shihab in one of his works "Mu'jizat al-Qur'an: Ditinjau dari Aspek Kebahasaan, Isyarat Ilmiyah dan pemberitaan Ghaib", defines the Koran as the words of Allah conveyed by the angel Gabriel (Indonesian: Jibril) in accordance with his editorial staff to the Holy Prophet and is accepted by Muslims. Nasr Hamid Abu Zaid gave the meaning of the Koran, while according to him, the Koran is a form masdhar of the word qara'a which means over and over. This is because

6 Said Agil Husin Al Munawwar, Al-Qur'an Membangun Tradisi Kesalehan Hakiki (Jakarta: Ciputat Press, 2003), 4.

7 Taufik Adnan Amal, Rekonstruksi Sejarah Al-Qur'an (Tanggerang, PT Pustaka Alvabet, 2013), 46.

${ }^{8}$ Muhaimin Zen, Al-Qur'an Seratus Persen Asli Sunni-Syi'ah Satu Kita Suci (Jakarta: Nur Al-Huda, 2012), 49.

${ }^{9}$ Nur Efendi and Muhammad Fathurrohman, Studi Al-Qur'an: Memahami Wahyu Allah secara Integral dan Komprehensif (Yogyakarta: Kalimedia, 2016), 40.

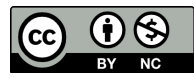

DOI: 10.19105/karsa.v29i1.2345 
the text was formed through oral tradition; the written tradition at that time did not yet have a significant role. ${ }^{10}$

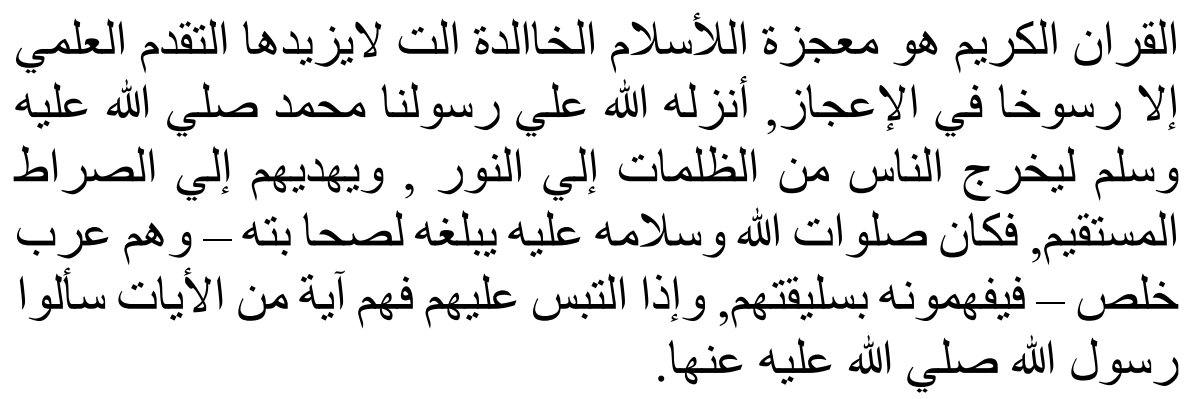

So as a conclusion that the Koran is the holy book of believers sent down by Allah to the Prophet Muhammad through the angel Gabriel according to its editorial, written in the mushaf and has the value of worship for those who read it, and he can contemplate the verses and want to remember, starting from al-fatihah to al-Nas. ${ }^{11}$

\section{Definition of Socio-Culture}

The word social is defined in the General Indonesian Dictionary: (everything) which is about society; in charge of taking care of the good and welfare of the community; associations, and associations that are social in nature and aim at (not commercial or political); likes to pay attention to the public interest (like to help, to give, etc.) so that the word social can be interpreted; traits society. ${ }^{12}$ According to M. Rafiek, what is meant by social is the basics of social life. Social Having to do with the reciprocal relations of interacting human beings, either as

\footnotetext{
${ }^{10}$ Nasr Hamid Abu Zaid,Tekstualitas Al-Qur'an: Kritik Terhadap Ulumul Qur'an, trans. Khoirun Nahdliyyin (Yogyakarta: LKIS, 2001), 50.

${ }^{11}$ Manna' Khalil Qaththan, Mabahits Fii 'Ulumil Quran, trans. Mudzakir AS (Bogor: Litera Antar Nusa, 2009), 9.

12 Pusat Pembinaan dan Pengembangan Bahasa, Kamus Umum Bahasa Indonesia (Jakarta: PN. Balai Pustaka, 1976), 961.
}

\section{(c) $($ i) (8)}

DOI: $10.19105 /$ karsa.v29i1.2345 
individuals or groups. ${ }^{13}$

The culture known by the term foreign comes from the Latin word "colere". This means cultivating or working, namely cultivating the land or farming. From the origin of this meaning, namely colere then culture, which is defined as all human power and activities to cultivate and change the earth. ${ }^{14}$ The word culture, when viewed in the General Indonesian Dictionary means; mind, mind, e.g., result -; culture; e.g.; language magazine. Regarding a culture that has developed (centuries), advanced); i.e., the soul that -, a developed soul (intelligent, advanced), language-,language that is the support (reader) of culture. The word culture itself can be interpreted as the result of the activities and creator of the human mind (mind, etc.) (such as belief, art, customs, and so on). ${ }^{15}$

Culture comes from the root of the Sanskrit word, namely bhud, which means "mind". Culture means "fruit of mind". Culture is defined as "the result of human creative cultivation". The word culture "comes from the Sanskrit language "buddhaya" the plural form of buddhi "which means" mind "or" intellect. Thus, culture is defined as the whole idea, work and human mind that it creates deliberately and continues to be developed for the sake of needs, welfare, peace, prosperity, and life satisfaction. ${ }^{16}$

Social can also be defined as social processes that are rewarded with mutual influence between various life together such as life economy and political life, legal life, and religious life, and so on, including the existence of social changes. ${ }^{17}$ The term culture, which is a foreign language term that has the same meaning as culture comes from

\footnotetext{
${ }^{13}$ Henry Pratt Fairchilhd, Dictonary of Sociology (New York: Littlefield, Adams \& Company, 1977), 275.

14 Soeryono Soekanto, Sosiologi Suatu Pengantar (Jakarta : Rajawali Press, 1989), 172.

${ }^{15}$ Pusat Pembinaan dan Pengembangan Bahasa, Kamus Umum Bahasa Indonesia, 961.

${ }^{16}$ M. Rafiek, Ilmu Sosial \& Budaya Dasar (Yogyakarta: Aswaja Presindo), 1.

17 Elly M. Setiadidan Usman Kolip, Pengantar sosiologi: Pemahaman Fakta dan Gejala Permasalahan Sosial; Teori Aplikasi, dan Pemecahannya (Jakarta: Kencana Prenada Media Group, 2011), 3.
}

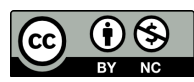


the Latin word colere, which means cultivating or working, namely cultivating the land or farming. From the origin of the word, namely colere then culture, interpreted as all human power and activities to cultivate and change nature. ${ }^{18}$

\section{Socio-Cultural Phenomena}

\section{Socio-Cultural Phenomena in the Age of the Prophet}

Based on QS al-Baqarah [2]: 221

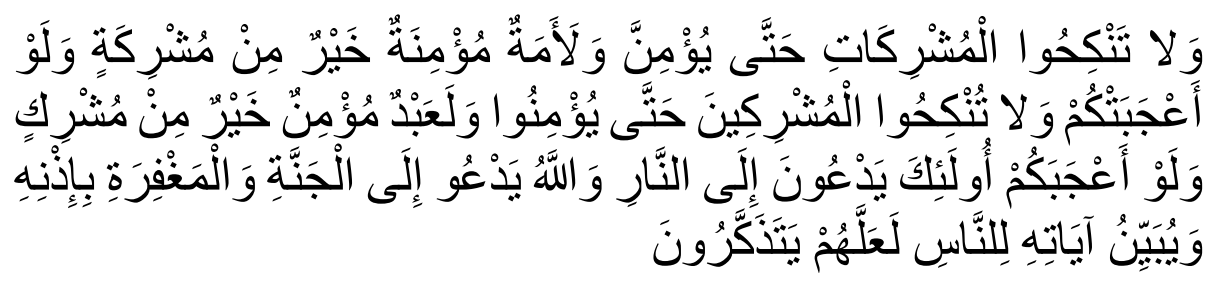

"Marry not the women who associate others with Allah in His Divinity until they believe; for a believing slave-girl is better than a (free, respectable) woman who associates others with Allah in His Divinity, even though she might please you. Likewise, do not give your women in marriage to men who associate others with Allah in His Divinity until they believe; for a believing slave is better than a (free, respectable) man who associates others with Allah in His Divinity, even though he might please you. Such people call you towards the Fire, and Allah calls you, by His leave, towards Paradise and forgiveness; and He makes His injunctions clear to people so that they may take heed."

In a history, it is stated that the decline "wa la tankihul musyrikati hatta yuminna" as an indication of the request of Ibn Abi Murtsid Al-Ghanawi, who asked permission from the Prophet SAW to marry a beautiful and respected idolatrous woman. ${ }^{19}$ Buya Hamka explained in his interpretation that this verse was revealed because of

${ }^{18}$ Soekanto, Sosiologi Suatu Pengantar, 72.

${ }^{19}$ KH. Qamaruddin Saleh \& H.A.A. Dahlan, Asbabun Nuzul Latar Belakang Historis Turunnya Ayat-ayat Al-Qur'an (Bandung: Diponegoro, 1986), 214,

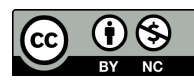

DOI: $10.19105 /$ karsa.v29i1.2345 
the story about Abdullah bin Rawahah slapping his black slave girl because so annoyed, even though black, but he was very pious. After he slapped him, Abdullah bin Rawahah regretted it, and his remorse was reported to the Messenger of Allah. After being freed and married to him, a lot of gossips circulated that someone like Abdullah bin Rawahah, who would not lack girls who wanted him if he wanted to, but now he married a black-skinned slave. Then the verse came down; ${ }^{20}$ so is the reverse verse, "And do not marry an idolatrous man after he believes."

The sound of the marriage ban from the Koran surah al-Baqarah [2]: 221 above is focused on the word mushrikāh. M. Quraish Shihab said that the Qur'anic experts have also provided an explanation of the meaning of the word. According to their observations, the words (مشركين) (مشرك) mushrik or (مشركين) mushrikn and (مشركات) mushrikāt, these words are used by the Qur'an for certain groups who associate partners with Allah. They were pagans who resided in Mecca. ${ }^{21}$

The Qur'an mentions the word "shirk" with all its derivations 168 times, spread over 44 surahs. The many surah are not only Makkiyah suras, but also Madaniyyah surahs. The surah that mentions the word "shirk" is surah al-'An 'àm [6], 29 times. If only viewed from the words mushrik, musyriküna, musyrikn, and musyrikät there are 49 words, which are spread in 18 suras. The surah that mentions the most between of the four words is surah al-Taubah [9] 9 times, and the most frequently mentioned word is mushrikn 36 times. ${ }^{22}$

Imam al-Tabarī, who argues that the prohibition of marrying polytheist women in surah al-Baqarah [2]: 221, is not included in it Ahl al-Kitab (for Christian). In his commentary, he also cites an opinion that explains that the polytheist women in question are the musyrikat of Arabs for whom they do not have a book. ${ }^{23}$ As for al-Razi himself, he

\footnotetext{
${ }^{20}$ Hamka, Tafsir al-Azhar jilid 1 (Jakarta: Gema Insani, 2015), 424.

${ }^{21}$ M. Quraish Shihab, Tafsir Al-Mishbah: Pesan, Kesan dan Keserasian Al-Qur'an (Jakarta: Lentera Hati, 2002), 577.

${ }^{22}$ Fu'ād Abdul Bāqī, Al-Mu 'jam al-Mufahras li al-Fāzail Qur'ānil Karīm (Kairo: Dār al-Kutub al-Misriyyah, 1364 H/1944M), 379-381.

${ }^{23}$ Ibn Jarīr al-Ṭabarī, Jāmi ' al-Bayān 'an Ta'wīlì al-Qur'ān (Kairo: Dar Hajr, $1422 \mathrm{H} / 2001 \mathrm{M}), 716$.
}

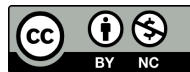

DOI: 10.19105/karsa.v29i1.2345 
tends not to include women Ahl al-Kitab into the polytheist group. It is based on the fact (grammatical) of the separation of mentions with the letter 'ataf between terms Ahl al-Kitab with the term polytheism in general in the Qur'an. For example, what is stated in the QS al-Hajj [22]:17. ${ }^{24}$ Likewise the surah contained in al-Bayyinah [98]:1. according to Imam al-Baithāwī disbelievers are divided into two groups, namely the Ahl al-Kitāb and the polytheists. ${ }^{25}$

The word al-mushrik found in QS al-Baqarah [2]: 221, are women who worship idols like the Arabs. The verse emphasizes that it is not permissible for a Muslim to marry a polytheist woman, just as it is forbidden for a Muslim woman to marry a polytheist man because of the vast difference between their two religions. Muslims invite to heaven, while the polytheists invite to hell. They (Muslims) believe in Allah, Prophethood, and the Judgement Day, while the polytheists associate partners with Allah, deny prophethood, and do not believe in the hereafter. Yusuf al-Qardāwi $\overline{1}$ wonders how can the purpose of marriage to get love can be achieved while the two partners are far from each other. ${ }^{26}$

The prohibition of Muslim marriages with polytheists, because they invite them to hell "They are inviting you to hell." You are a people of monotheism, while they still maintain polytheism. They will invite you to go to hell only, both the hell of the world because of the chaos of the mind in the household and the hell of the hereafter because their invitations are not true what's more if you get children from such a marriage. The child's mental growth will not be peaceful under the care of a father and mother who are different. ${ }^{27}$ Al-Qurtubī also quotes opinion Some 'ulama' who say that the editor of the verse (أُوَيَّكَ لُى النَّار) is used as 'illat al-Hukum (law cause) in the prohibition of marriage

\footnotetext{
${ }^{24}$ Suhadi, Kawin Lintas Agama Perspektif Kritik Nalar Islam (Yogyakarta: LkiS, 2006), 31.

${ }^{25}$ Al-Baiḍāwī, Anwār al-Tanzīl wa Asrār al-Ta'wīl (Beirut: Dār Ihyyā' al-Turās̀ al'Araby, 1418H/1998M), 328.

${ }^{26}$ Yusuf al-Qarḍāwī, Al-Halāl wa al-Harām fì al-Islām (Kairo: Maktabah Wahbah, 1993), 163.

${ }^{27}$ Hamka, Tafsir Al-Azhar (Jakarta: Gema Insani, 2015), 424-425.
}

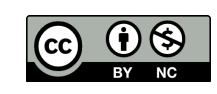

DOI: $10.19105 /$ karsa.v29i1.2345 
with idolatrous women because they invite to hell. ${ }^{28}$ Likewise with M. Quraish Shihab, according to him, the polytheists invite their partners to hell and the children who will be born. He invites through words or deeds and example. ${ }^{29}$

Abd. Moqsith Ghazali does not agree with what some scholars have said about the illat; he said if it is an illat al-Hukum (law cause) for the prohibition of interfaith marriage, the prohibition is not only on polytheists, marriage with a person who has the potential to invite someone to a crime, regardless of the type of religion, can be prohibited. Through a fragment of the verse called 'illat al-Hukum above, according to M. Quraish Shihab, the verse gives the impression that everyone who invites to hell is an unnatural person to be a life partner. ${ }^{30}$ Q.S. al-Ahzab [33]: 59

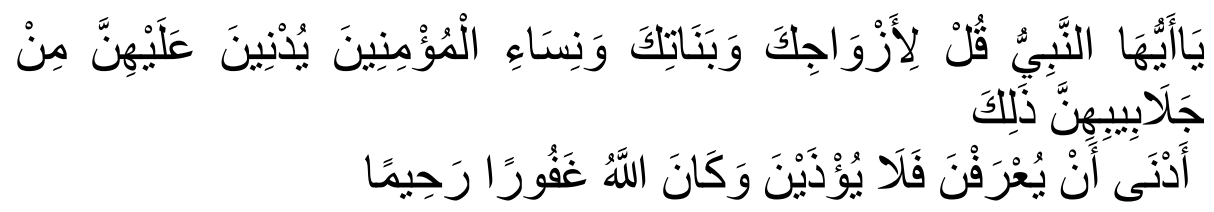

"O Prophet, urge your wives and your daughters and the believing women to draw a part of their outer coverings around them. It is likelier that they will be recognized and not molested. Allah is Most Forgiving, Most Merciful."

This verse was revealed when the wife of the Prophet, namely Sawdah, left the house for some purpose. His tall and large body made him easily recognized among other women; when he walked, Umar saw

\footnotetext{
28 Abū 'Abdillah Muhammad Ibn Aḥmad al-Qurțub̄̄, Al-Jami' li Ahkām alQurān wa al-Mubayyin limā Tadammanah min al-Sunnah wa Āy al-Furqān (Beirut: Mu'asasah al-Risalah), 457.

${ }^{29}$ M. Quraish Shihab, Tafsir Al-Mishbah: Pesan, Kesan dan Keserasian Al-Qur'an (Jakarta: Lentera Hati, 2002), 581.

30 Abd. Moqsith Ghazali, Argumen Pluralisme Agama; Membangun Toleransi Berbasis Al-Qur'an (Depok: KataKita, 2009), 338.
} 
him and rebuked him. O Sawdah, by Allah, we can recognize you easily. So what business are you out? He hurried over and met the Prophet eating at Aisyah's house. Then Sawdah came in and said, O Messenger of Allah I was going out for some reason, then Umar saw me and ordered me. And come down this verse. ${ }^{31}$

Q.S. al-Baqarah [2]: 256

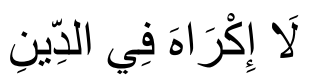

"There shall be no compulsion in [acceptance of] the religion."

This verse was revealed before the Madina people embraced Islam; they felt that the life of the Jews was better than them because they were ignorant. For this reason, some of them gave up their children to the Jews, and when they were adults, they converted to Judaism. After they converted to Islam and welcomed the Prophet, they become the Anshar. So after the Prophet moved, an agreement was made with good standing with the Jewish tribe. The agreement was violated, and the Nadhir people were expelled from Medina, and one of the Ansar's children joined them so that his father felt sad and ordered him to be withdrawn to Islam even though he was forced. So this verse comes down. ${ }^{32}$

The Qur'an expressly prohibits the coercion of others to convert to Islam as stated in surah al-Baqarah/2: 256. It is very clear that the Qur'anic view that the responsibility of the state to maintain religious diversity will only be carried out properly if the state really guarantees that there is no compulsion in that country to convert to Islam. According to M. Quraish Shihab, "Why is there coercion when $\mathrm{He}$ (Allah) does not need anything? Why is there compulsion, when if Allah

\footnotetext{
${ }^{31}$ Muhammad Chirzin, Buku Pintar Asbabul Nuzul: Mengerti Peristiwa dan Pesan Moral di Balik Ayat-ayat Suci Al-Qur'an (Jakarta: Zaman, 2011), 333.

${ }^{32}$ Hamka, Tafsir Al-Azhar, 513.
}

\section{(c) $\underset{\mathrm{BY}}{(\mathrm{i})(\mathrm{NC})}$}

DOI: 10.19105/karsa.v29i1.2345 
had willed $\mathrm{He}$ would have made you one people (alone) (alMaidah/5:48)." 33

Abu Muslim and al-Qaffal argue this verse wants to emphasize that faith is based on a conscious choice and not on pressure. ${ }^{34}$ According to Muhammad Nawawi al-Jāwi, this verse states that coercion to enter religion is not justified. ${ }^{35}$ In this case, the prohibition of coercion needs to be interpreted more broadly, namely the prohibition of acts of violence in the name of religion. If coercion is prohibited, let alone the destruction of houses of worship. This is where the verse has a wider impact in order to build a harmonious and tolerant religious life. ${ }^{36}$

\section{The Social and Cultural Phenomena of the Koran in Society}

a. Knowledge

Regarding science (science), many verses of the Koran talk about science. Such as solar phenomena and orbits, which according to solar astronomers, move as far as $17,280,000 \mathrm{~km}$ in a day. The phenomenon of the solar system and orbit globally has been described in the Koran, among others, in surah al-Anbiya [21]: 33

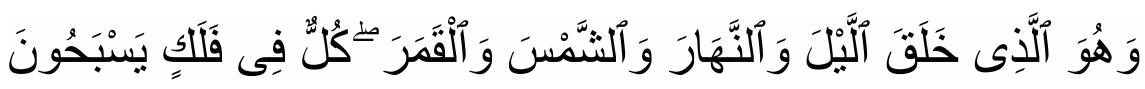

"And He is the One Who created the day and the night, the sun and the moon--each traveling in an orbit."

b. Trust

Pregnant mother's belief in several verses read before childbirth, among the verses referred to is surah ar-ra'd [13]: 8, fatir [35]: 11, an-nahl [16]: 78, al-zalzalah [99]: 1-8. Some of these verses

33 Kementrian Agama RI, Al-Qur'an dan Kebhinekaan (Jakarta: LPMA Badan Litbang dan Diklat Kemenag RI, 2011), 315.

${ }^{34}$ Fakhr al-Din al-Razi, Mafātih al-Ghaib (Beirut: Dar Ihya' at-Turats, 1999), 15.

${ }^{35}$ Muhammad Nawawi al-Jawi, Marāh Labīd (Beirut: Dar al-Kutub al-Ilmiyah,1997), 94.

${ }^{36}$ Zuhairi Misrawi, Al-Qur'an Kitab Toleransi (Jakarta: Oasis, 2010), 227.

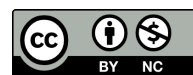

DOI: $10.19105 /$ karsa.v29i1.2345 
are believed to be able to launch the labor process with the belief that it is all by Allah's permission.

c. Art

In this case, it is about how people make the verses of the Koran into art. There are so many various expressions of beauty through the verses of the Koran that are explored in the form of calligraphy and recitation, and so on.

d. Moral

The phenomenon of the verses of the Koran about doing good to parents is common in society as a whole, be it Muslims or nonMuslims. They do good to their parents, respect them, even though there are those who do not realize that there are verses that allude to respect for their parents, which is in the surah al-isra' [17]: 23:

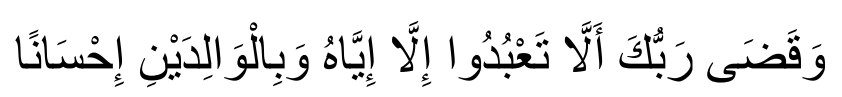

"For your Lord has decreed that you worship none but Him. And honour your parents."

e. Law

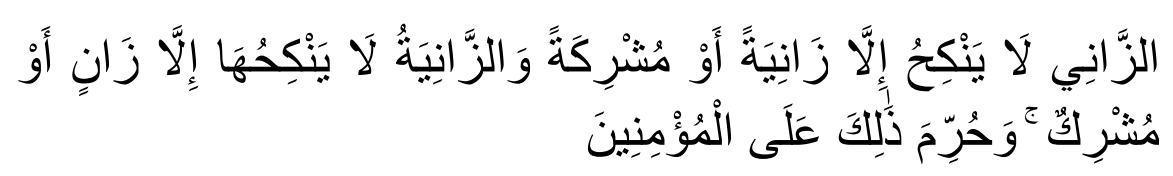

"A male fornicator would only marry a female fornicator or idolatress. And a female fornicator would only be married to a fornicator or idolater. This is 'all' forbidden to the believers."

This verse applies to people in North Sumatra; if a woman and man are found to have committed adultery, they will immediately be married off; according to their belief, part of the ethics is that men who commit adultery should marry women who commit adultery as

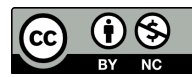

DOI: 10.19105/karsa.v29i1.2345 
well. This is because the act will be a disgrace to the family. And if the man does not want to marry the woman, the woman's extended family will visit him to be forced to marry the woman.

\section{f. Custom}

Regarding the reading of the Koran that occurs in the community in the North Sumatra region, as is usually done at the traditional wedding and circumcision events, as well as before the corpse is buried, increase learning from iqra' (read) to the Koran, before school graduation and others. In terms of the procession of activities, usually, people carry out a habit that makes it a culture by parading someone who will carry out the process of understanding the Koran and usually the one who will make a tumpeng from yellow pulut and cook pulut (alike sticky rice) mixed with coconut core and boiled eggs and so on.

\section{Definition of Living Al-Qur'an}

In terms of language, the Living Qur'an is a combination of two different words, namely living, which means 'life', and Qur'an, which is the holy book of Muslims. In simple terms, the term Living Qur'an can be interpreted as "the Qur'an (text) that lives in society." ${ }_{37}$ The Living Qur'an essentially stems from the phenomenon of the Qur'an in Everyday Life, namely the meaning and function of the Qur'an, which is really understood and experienced by the Muslim community. In other words, the functioning of the Qur'an in practical life outside of its textual conditions. The functioning of the Qur'an like this arises because of the practice of interpreting the Qur'an, which does not refer to the understanding of its textual message but is based on the assumption that there is "fadilah" from certain units of the Qur'anic text, for the practical daily life of the Muslim community. ${ }^{38}$

37 Sahiron Syamsuddin, ed., "Ranah-Ranah Penelitian dalam Studi al-Qur'an dan Hadis," in Metode Penelitian Living Qur'an dan Hadis (Yogyakarta: Teras, 2007), xiv. ${ }^{38}$ M. Mansur, "Living Qur'an dalam Lintasan Sejarah Studi Al-Qur'an," in Metode Penelitian Living Qur'an dan Hadis, ed. Sahiron Syamsuddin (Yogyakarta: Teras, 2007). 5.

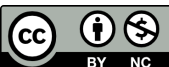

DOI: $10.19105 /$ karsa.v29i1.2345 
The term Living al-Qur'an, in other technical terms, is also called interaction or reception. The word reception can be used to represent the behavior of the interaction between the Qur'an and its adherents. According to Nur Kholis Setiawan, theoretically, there are three forms of the public reception of the Koran. First, cultural reception, which tries to reveal the influence and role of the Koran in shaping the culture and culture of society. The second is hermeneutic reception, which reveals developments related to the study of text interpretation and the activity of text interpretation itself. The third is aesthetic reception, which reveals the process of receiving with the eyes and ears, the experience of art, and the taste of an object or appearance. Thus the locus of the study of the Living Qur'an is in the cultural and aesthetic reception. ${ }^{39}$

Sam D. Gill put forward the informative and performative aspects of the scriptures, including the Qur'an. The informative function aspect is when the Qur'an positions itself as a provider of information to its readers, either in the form of guidelines ( $h u d a$ ) or others. Meanwhile, the performative aspect is when the Qur'an is positioned by someone as something that is treated, for example, as wirid, and other traditions. A text becomes sacred because of the respect and special treatment of the people who believe in it. So that the study of scripture does not stop at purely normative aspects but also includes historical studies. In the language of Sam D. Gill, the normative aspect of the scriptures is called the informative function, while historical studies are the existence of the performative function of the scriptures.

Sam D. Gill explained that the informative function focuses on how religious adherents appreciate the holy book by understanding the meaning contained in it. This aspect is reflected in the function of the holy book as a text that is read, understood, and practiced. One example is the Koran which has produced many works of interpretation as a form of informative analysis of the holy book. In contrast, the performative function emphasizes the efforts of symbolic expression of religious

\footnotetext{
${ }^{39}$ Muhammad Nur Kholis Setiawan, al-Qur'an Kitab Sastra Terbesar (Yogyakarta: elsaq Press, 2006), 68.
}

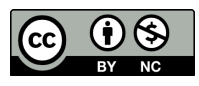

DOI: $10.19105 /$ karsa.v29i1.2345 
adherents that can appear from the inside and outside of the holy book. One example is the Koran which has produced many works of interpretation as a form of informative analysis of the holy book. At the same time, the performative function emphasizes the efforts of symbolic expression of religious adherents that can appear from the inside and outside of the holy book. One example is the Koran which has produced many works of interpretation as a form of informative analysis of the holy book. In comparison, the performative function emphasizes the efforts of symbolic expression of religious adherents that can appear from the inside and outside of the holy book. ${ }^{40}$ In this context, it gives birth to religious rituals and how then the holy book is treated as a medium to treat disease, expel genie, reject reinforcements, and others. One of them is also the wirid tradition of the Lubuk Bayas community. And in each of these traditions, certain verses are read, such as reading the verse of the al-fatiha, yasin, al-ikhlas and others.

The informative aspect of the Qur'an is interpreted as a form of public response that makes the scriptures a source of knowledge, teachings, history, scientific instructions, and so on. Meanwhile, from the performative aspect, the holy book is experienced, used as a sacred object, held firmly and sacredly, used as a source of state or community law, used as a tool to bless, to be heard and contested, and so on. Performative and informative functions are possible in communities that do not highlight the literal role of text. According to Sam D. Gill, this situation is not caused by the inability of one community to understand the text but rather the scientific factor they have. However, in the non-Arab community, the existence of the text in everyday life is more important than the literal meaning and content of the text. In the pattern of interaction with the Qur'an, there are two models of interaction of Muslims with the Qur'an, interaction with the text that results in understanding the text and interaction with the text that produces actions and behavior. ${ }^{41}$ Therefore, the Koran, which is

40 Sam D. Gill, "Nonliterate Tradition and Holy Books," in The Holy Book in Comparative Perspective, ed. Federick M. Denny and Rodney L. Taylor (Colombia: University of South California Press, 1993), 224-238.

${ }^{41}$ D. Gill, "Nonliterate Tradition and Holy Books," 224-238.

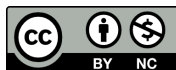

DOI: $10.19105 /$ karsa.v29i1.2345 
believed to exist as a holy book for Muslims, cannot be separated from its function as informative and performative. Through their elaboration, both gave birth to religious practices which are directly or indirectly sourced from the spirit of the Qur'an. ${ }^{42}$

In Jean Dammen McAuliffe's findings regarding the Qur'an and the reception of the Islamic community, he said that among several holy books, the Qur'an is a holy book that has a strong appeal (powerful). This attraction causes the Qur'an to be read and studied by every Muslim and non-Muslim. On that basis, McAuliffe mapped the factors that cause the Qur'an to have such advantages. He found three factors that can answer this phenomenon, namely carnal factors (physical), conceptual factors (intellectual), and communal factors (social). The factor of Carnal (physical), the Qur'an is practiced directly, which involves physical interaction, such as reading and listening to the chanting of verses. Conceptually, society interacts with the Qur'an by making it an object of research and reflection. ${ }^{43}$

In the pattern of interaction with the Qur'an, as previously explained, Sam D. Gill divides it into two models of interaction between Muslims and the Qur'an, interaction with the text that results in understanding the text and interaction with the text that produces action and behavior. ${ }^{44}$ The second model of interaction above can be seen, for example, by reading and memorizing the Qur'an, treatment with the Qur'an, asking for various things with the Qur'an, expelling spirits with the Qur'an, applying verses certain verses of the Qur'an in individual life as well as in social life. Social reception of the Qur'an can be found in everyday life, so the Qur'an that "lives" in society is also called the living Qur'an. ${ }^{45}$

\footnotetext{
42 Rahmatullah, "Aspek Magic Surat al-Ikhlas dalam Kitab Khazinat al-Asrar," QUHAS: Jurnal of Qur'an and Hadith Studies 7, no. 1 (Spring 2018): 45, https:// doi.org/10.15408/quhas.v7i1.13389.

43 Muhammad Zainul Hasan, "Resepsi Al-Qur'an sebagai Medium Penyembuhan dalam Tradisi Bejampi di Lombok," Jurnal Studi Ilmu-ilmu al-Qur'an dan Hadis 21, no. 1, (Spring 2020), 134, https://doi.org/10.14421/qh.2020.2101-07.

${ }^{44}$ D. Gill, "Nonliterate Tradition and Holy Books," 234.

${ }^{45}$ Hasan, "Resepsi," 139.
}

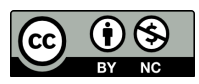

DOI: 10.19105/karsa.v29i1.2345 


\section{Discussion}

\section{The Virtues of Reading in the Wiriddan Tradition}

The term tradition in writing by Talal Asad has two ways: first, as a theoretical location for asking questions of authority, timing, use of language, and embodiment; and second, as an empirical setting in which discursiveness and materiality are linked through the minutiae of everyday life. The aspect of discursive tradition is basically a matter of linguistic actions that are passed down from generation to generation as part of the form of life, a process in which a person learns and relearns how to do things with words, sometimes reflectively and sometimes without thinking. Embodied practice helps in the acquisition of talent, sensitivity, and tendency through repetition. Through such practices, one can change oneself - one's physical being, one's emotions, one's language, one's inclinations, as well as one's environment. Tradition opposes empirical theories of knowledge and relativist theories of justice. What Talal Asad means first and foremost is that tradition emphasizes critical learning over abstract theory. Empirical theories of knowledge affirm the centrality of sensory experience and evidence, but in doing so, they ignore it. ${ }^{46}$

Regarding tradition, there is disagreement; historians have traced the beginnings of modern criticism of tradition to the clashes between ancients and moderns in the second half of the seventh and first half of the eighteenth century. Many modernists see the current crisis of Arab society as rooted in unquestioning attachment to religious traditions. The famous poet Adonis, for example, has written at length about the need to break firmly with tradition (salafiyya). A proponent of revolutionary change in Arab society, he urged "the need to free Arabs from all dependence on tradition, the need to remove the sacredness of the past and regard it as part of experience or knowledge with which one has no obligation [ghayr mulzima itlaqan]. "This modern idea of choice stands in stark contrast to past ideas that were

\footnotetext{
46 Talal Asad, "Thinking About Tradition, Religion, and Politics in Egypt Today," The University of Chicago Press Journals 42, no. 1 (Spring 2015), 166, https://www. journals.uchicago.edu/doi/pdf/10.1086/683002.
}

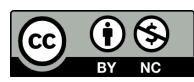


bound by language, ability, and affection. The old assumption that tradition is antimodern has been challenged in several ways. Adam Seligman and his colleagues have recently argued that the formal character of ritual has the function of smoothing out social life where rigid adherence to one's actual feelings (sincerity) would be very disturbing. Therefore, the theoretical object of submitting to ritual is not the suppression of authentic feelings but their management using conventional formalities so that social life becomes possible. ${ }^{47}$

Shaykh Muhammad bin Ali Al-Khird classifies wirid or dhikr by dividing it into three types, namely: First, verbally, such as glorifying, praying and the like. Second, with the heart and full of sincerity, present God in him. Third, eliminating the form of dhikr in people who do dhikr because they are immersed in the ocean of mushahada (or mushahida: contemplation, witnessing, derived from shuhud to witness, is a concept in sufism) to Allah swt. ${ }^{48}$

The wiriddan tradition is carried out twice a week, once for male congregations and once for female congregations. Male congregations carry out the wiriddan tradition on Thursday nights (Friday nights), to be precise when the maghrib prayer is finished, usually starting at 19.00 $\mathrm{pm}$ local time (Western Indonesian Time). As for the women congregation the wirid tradition is carried out the next day, which is when the congregational prayer is finished on Friday. In carrying out the wiriddan tradition, the verses of the Koran recited by the people of Lubuk Bayas village include surah yasin. In addition, people also read takhtim and tahlil as well as surah al-ikhlas, al-falaq, al-nas. Once every two weeks, there is a recitation guided by the local ustaz to deliver a short lecture.

Regarding the adjustment of the day, according to Mrs. Rina, ${ }^{49} \mathrm{~A}$ resident of Lubuk Bayas Village who is also an active congregation wiriddan said that the belief of community on Friday nights and during

\footnotetext{
${ }^{47}$ Asad, "Thinking," 170-171.

${ }^{48}$ Abdul Hafidz and Rusydi, “Konsep Dzikir dan Do’a Perspektif Al-Qur'an,” Islamic Akademika: Jurnal Pendidikan dan Keislaman 6, no. 1 (Spiring 2019), 62, https://doi. org/10.230303/staiattaqwa.v6i1.79.

${ }^{49}$ Rina Fauziah, Interview, April 1, 2019.
}

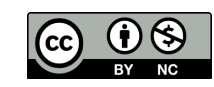

DOI: $10.19105 /$ karsa.v29i1.2345 
the day there is a lot of goodness. He mentioned that Adam was created on Friday, was put into heaven, and was expelled from him on Friday, and the end of the world will happen on Friday. Then he added that on Friday night and the next day is a very time it is impossible to ask for something from Allah SWT. As for why women do it during the day and men at night, according to Mrs. Rina because it is more of a safety factor, moreover, the distance traveled by the female covers one hamlet, so in Lubuk Bayas Village every Friday night, there are four houses of the male and female congregation as ahl-Bait because in Lubuk Bayas Village there are four hamlets.

Tradition is very decisive in the continuity of the syiar of Islam when tradition and culture are integrated with Islamic teachings. Because tradition is flesh and blood in a certain society while changing traditions is something that is very difficult, it is a wise step when tradition is not positioned against the teachings, but rather tradition as the door to religious teachings. Mr. Fauzi ${ }^{50}$ as an active community of male officers and congregations said, there were a lot of fadilah and wisdom in reading the verses in wiriddan tradition, which he heard and still remembers when a religious teacher conveyed fadilah reading the verses that were intended. Are as follows, among them, for those who always read the surah al-ikhlas, they will get priority as if they have read a third of the Koran, while reading of surah yasin will be rewarded like reading the Koran ten times and will be fulfilled when reading qul huwallahu ahad and al-mu'awwidzataini.

What was conveyed by Mr. Fauzi regarding fadilah reading of certain suras in wiriddan, can be clarified by including arguments that are considered similar to what the speakers mean. Surah al-ikhlas ${ }^{51}$ read in the wiriddan tradition is as prayer in that tradition, with the intention of achieving everything that is intended (desired). Keep away from all dangers and disasters. Save yourself from the evil of the greedy people, avoid hunger and thirst, and avoid slander and torment of the grave, and also get the good of the world and the hereafter. By asking Allah for

\footnotetext{
${ }^{50}$ Muhammad Fauzi, interview, April 3, 2019.

${ }^{51}$ This is as said by the Prophet Muhammad. "Whoever reads the surah al-ikhlas, it is as if he has read a third of the Koran.".
} 
what he means and doing it with confidence and patience, Allah will always be happy with His servants who always pray and ask Him. ${ }^{52}$

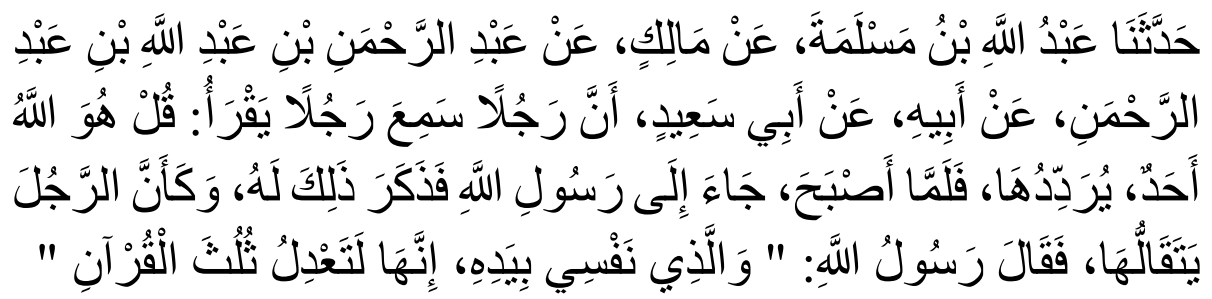

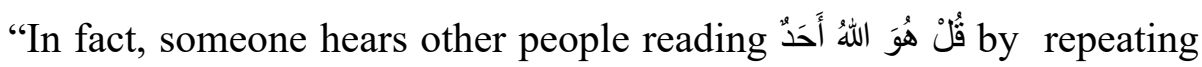
it, then when in the morning, he comes to the Messenger of Allah and tells him about it, and as if that person underestimated the letter, the Messenger of Allah sallallahu 'alaihi wa sallam: "For the sake of the Essence whose soul is in His hands, in fact, that surah is equivalent to one-third of the Qur'an."

Hadith The virtue of reading yasin dan qul huwallahu ahad and al-mu'awwidzataini:

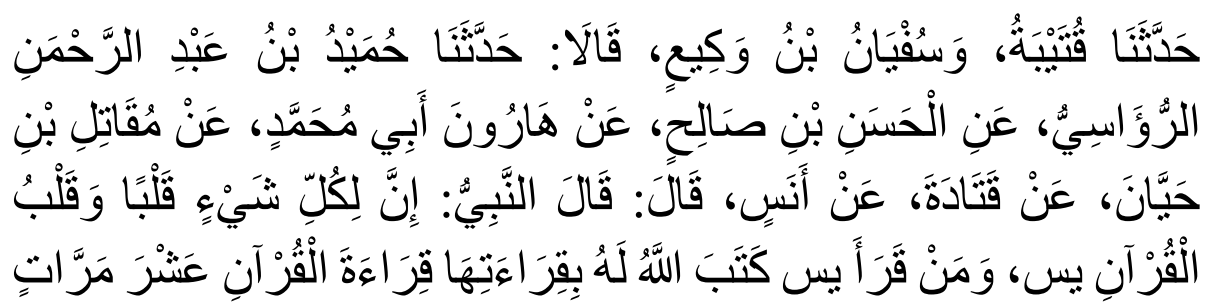

"Everything has a heart. The heart of the Koran is surah yasin. Whoever reads surah yasin, Allah will record for him it is like reading the Qur'an ten times."

\footnotetext{
${ }^{52}$ As for the letter al-Falaq, for those who read it, it will remove from within itself the feeling of fear from the temptations and disturbances of Satan, human cruel, and the darkness of the night this surah of the Koran also serves to keep humans from disturbing animals. As Aisyah explained that Rasulullah saw, every night when he was going to sleep, he read sura al-Ikhlas, al-Falaq, and sura al-Nas. Romadoni Muslim, Do 'a-do'a Qur'ani (Jakarta: Intimedia Ciptanusantara, 2002), 153-156.
}

\section{(c) $\underset{\mathrm{BY}(\mathrm{NC})}{(2)}$}

DOI: $10.19105 /$ karsa.v29i1.2345 


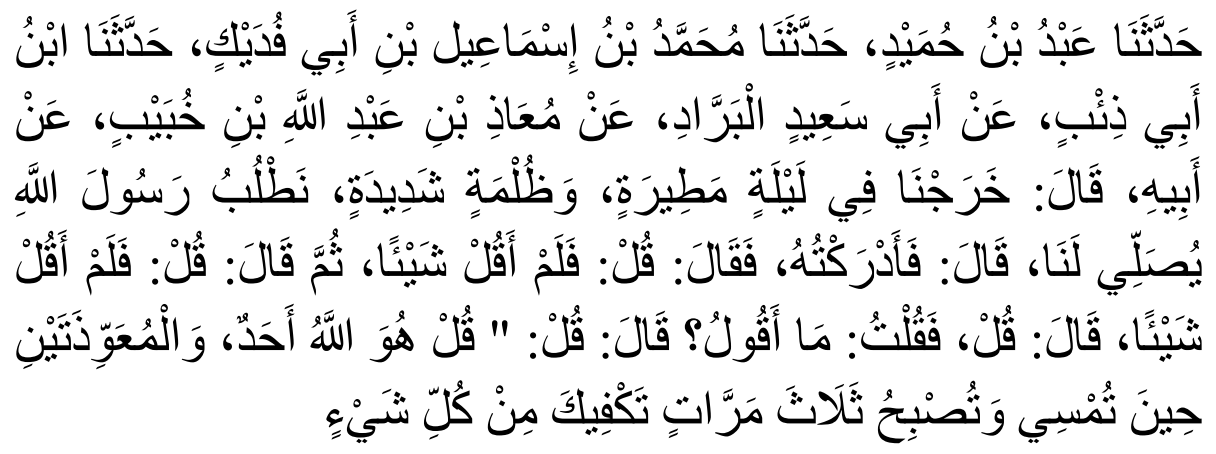

"Whoever reads it (qul huwallahu ahad and almu'awwidzataini: qul a'udzu bi rabbil falaq and qul a'udzu bi rabbin naas) 3 times in the morning and evening, then everything will be sufficient for him."

In the implementation of a tradition that occurs in a certain society, of course there are things that underlie the basis for the occurrence of this tradition, both those found in the Koran and from the hadith of the Prophet. which is the guide for people who adhere to certain traditions. In this case, the wiriddan tradition that occurs in the community of Lubuk Bayas Village in reading yasin is motivated by the Prophet's hadith which reads, the Prophet said: "whoever reads the Yasin letter on Friday night, then the next day he is forgiven for his sins." Apart from that, there is also a hadith which says that, for anyone who reads surah yasin, Allah writes a reward for reading the Koran 10 times. ${ }^{53}$ Word of the Prophet Muhammad. this is what society holds. Meanwhile, the importance of reading surah al-ikhlas, al-falaq, and alnas has been alluded to in the previous discussion.

On the website of the Ministry of Religious Affairs of West Java Province, Nasim Surahman mentions 10 benefits of reading the Qur'an, including: Reading the Qur'an with a calm heart and a happy feeling can change someone who initially behaved badly for the better. According to him, reading the Koran with a sincere heart can dispel and

53 Sayyid Muhammad Alwi al-Maliki, Keistimewaan-Keistimewaan al-Qur'an (Yogyakarta: Mitra Pustaka, 2001), 237.

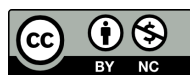

DOI: $10.19105 /$ karsa.v29i1.2345 
cure heart diseases which include envy, envy, likes to talk about the bad things of others, feel revenge and others other. This opinion is based on the hadith which states that:

"Indeed, this heart can rust like iron that becomes rusty when touched by water. They (his Companions) asked: how to keep this heart from rusting?, then the Messenger of Allah. Said believe by reading the Koran." 54

From what has been described, Nasim Surahman has a close relationship with Ibn Sina's opinion. According to him, the soul is a human spiritual organ whose influence is considered the most and even the greatest compared to other spiritual members, which can give orders to the bodily organs to act. ${ }^{55}$ Likewise, the results of Muhammad Yusuf's research states that the cultivation of religious values and local wisdom is able to form character, ${ }^{56}$ The character also teaches universal truths of honesty, integrity, other values of truth, and goodness. ${ }^{57}$

\section{Religious Social Values as Community Motivation}

From sociologically-anthropologically, the face of Islam Nusantara (Islam of the archipelago) is the result of acculturation of universal Islamic values with the local culture of the archipelago. This

\footnotetext{
${ }^{54}$ Nasim Surahman, "10 Manfaat Baca Al-quran setiap Hari yang Luar Biasa” (Portal Kantor Kementrian Agama Provinsi Jawa Barat, 2019), https://jabar.kemenag.go.id/ portal/read/10-manfaat-baca-al-quran-setiap-hari-yang-luar-biasa. (accessed Jun 9, 2021).

${ }^{55}$ Jarman Arroisi and Rahmat Ardi Nur Rifa Da'i, “Konsep Jiwa Perspektif Ibn Sina," ISLAMICA: Jurnal Studi Keislaman 13, no. 2, (Maret 2019), 258, https://doi.org/ 10.15642/islamica.2019.13.2.323-345.

${ }^{56}$ Character is defined as the character, psychological traits, morals, or character that distinguish one person from others. Subaidi, "Pendidikan Karakter Berbasis Budaya Islami di MTs. Tahfidz Yanbu'ul Qur'an Menawan Kudus," Tadris: Jurnal Pendidikan Islam 14, no. 2 (Spiring 2019). 190, https://doi.org/10.19105/tjpi.v14i2.2737.

${ }^{57}$ Muhammad Yusuf, "Pendidikan Karakter Berbasis Qurani dan Kearifan Lokal," Karsa: Journal of Social and Islamic Culture 22, no. 1. (2014), 53, https://doi.org/ 10.19105/karsa.v22i1.548.
}

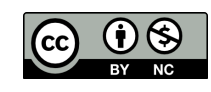

DOI: $10.19105 /$ karsa.v29i1.2345 
cannot be separated from the efforts of the propagator of Islam Nusantara, especially Walisongo, who puts forward the principle of dialogue, both in daily communication activities and local cultural dialogue. Local culture becomes a national identity in which there are exotic philosophical values that are very valuable for the process of life. However, there are challenges amid the strengthening of cultural globalization, which has led local cultures to the brink of extinction. ${ }^{58}$ As a community, we certainly have a role in preserving the existing local cultures.

There are many reasons why the wiriddan tradition is still continuing today. According to Mr. H. Hasan Siregar, ${ }^{59}$ as the elder of the local community, said that with the wiriddan tradition in Lubuk Bayas village community, this tradition was able to unite the bonds of brotherhood and strengthen ties in society, because this tradition is not just reading. Surah yasin, al-ikhlas, al-falaq, al-nas, takhtim, and takhlil only then the residents just go home to their respective homes, but after the end of the event, usually, the owner of the house provides food according to the taste and ability of the host to be served to residents who are present at night or day (especially wirid and women), when meals happen, of course at the same time it is also filled with talk. From this activity, there will be interactions between residents that can strengthen the relationship in the village community. Mr. H. Hasan Siregar also added that, in terms of consumption, there is no obligation to provide a certain menu, but it is the custom of the people to still provide a food menu even though it is only a few pieces and water. The people's willingness to provide consumption, namely because of the sense of community enthusiasm for alms and people's habits in honoring guests.

From the results of the interview with Mr. H. Hasan Siregar, the writer classified several social values contained in the wiriddan tradition in Lubuk Bayas Village, including the following:

\footnotetext{
${ }^{58}$ Mukhibat, "Meneguhkan Kembali Budaya Pesantren dalam Merajut Lokalitas, Nasionalitas, dan Globalitas," Karsa: Journal of Social and Islamic Culture 23, no. 2. (Spiring 2015). 178, https://doi.org/10.19105/karsa.v23i2.717.

${ }^{59}$ H. Hasan Siregar, interview 10 April, 2019.
}

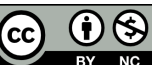

DOI: $10.19105 /$ karsa.v29i1.2345 
1. Gathering between residents

According to $\mathrm{Mr}$. Andi, ${ }^{60}$ the wiriddan tradition as a community forum to gather and stay in touch with each other. The social condition of the community, which is almost impossible to gather in large numbers because of several things such as work and others, is the right moment to make the wiriddan tradition a time for collective gathering in Lubuk Bayas Village. He also said that friendship is part of religious teachings, of course, in which there are various kinds of goodness.

2.Alms

In the wiriddan tradition, to be precise, after reading certain verses, the host offers a menu of food and drinks for the wirid congregation. As said by Mr. H. Hajan Siregar, it can be ascertained that almost no residents do not provide food menus during wirid events because of the people's enthusiasm for the values of goodness in giving alms.

3. Help each other

According to sister Leny ${ }^{61}$ as a member of the young women of the Nurul Iman Mosque, she said that in the wiriddan tradition, there is a help system in the form of finance, whose form is not determined, whatever the donor wants and is able to give to the committee who comes to their respective places members. The committee recorded how many forms of assistance were given, and usually, the one who was given assistance returned the assistance with a nominal amount. Sister Leny also said that the contribution system was not enforced for every member, only those who were pleased, and this system only applied to female congregations, not male congregations. This was because the number of female congregations was more compared to male congregations. Sister Leny added that in order for the distribution to look fair, the congregation agreed to implement a house-to-house shifting system if there was an obstacle, her neighbor to be willing to replace her.

\footnotetext{
${ }^{60}$ Dian Apriadi, interview, April 11, 2019.

${ }^{61}$ Leny Nurjanah, interview, April 14, 2019.
}

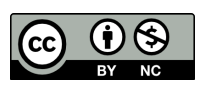

DOI: $10.19105 /$ karsa.v29i1.2345 


\section{Respect for Teachers}

According to Mr. Dahlan Siregar (interview, April 10, 2019), at the wiriddan event, usually, after the yasin reading was finished, there was a lecture delivered by the village recitation teacher. However, the wiriddan tradition does not teach every week but only once every two weeks. The recitation teacher is treated differently from other communities in terms of food dishes. The host usually gives packages of various foods that are in the host's house for the teacher to bring to his house. Everything is presented to the teacher who delivers tausiah, as a sign or a symbolic form of gratitude from the host. Thanks to his lectures, the public gained broad religious insights.

5.Dialogue between residents

The livelihood of the residents of Lubuk Bayas Village is farming, in this case, planting rice, because the Lubuk Bayas area is a rice field area. In farming, there is a lot to be discussed among the community, as stated by Mr. Syahrial ${ }^{62}$ as the head of the waters and also as the congregation wiriddan, he said that when he finished eating the meal, residents did not immediately rush home, usually between residents telling each other their complaints to other residents, so that other residents could provide solutions and understand the problems to residents affected by the problem or calamity that is being experienced. Mr. Syahrial also said that the most commonly discussed dialogue is about rice fields. Regarding who may be present at the wiriddan, Mr. Syahrial added that there is no provision regarding this matter. Anyone has the right to attend, even not only parents who attend the traditional event, teenagers and young children also enliven the tradition.

In terms of preserving the wiriddan tradition, according to $\mathrm{Mr}$. Fauzi ${ }^{63}$ The community has a very strong awareness of implementing and continuing to preserve this tradition. Even without being driven by religious or community leaders, the community continues to carry out this tradition. This fact shows that the beliefs they hold and they believe

${ }^{62}$ Syahrial, Interview, April 16, 2019.

${ }^{63}$ Fauzi, interview. 
are true without the interference of other people who order them, even though, in fact, there are certain groups who are unable to attend this traditional event. So, in general, the people in the village are very enthusiastic in carrying out the wirid tradition with the motive of looking for virtue and reward, as well as strengthening ties and sending prayers for someone who has died. The wiriddan tradition carried out by the community is a useful activity in the opinion of the author himself. Doing so can have values of worship such as reciting surah yasin, alikhlash, al-falaq, al-nas and takhtim, takhlil, rather than nothing at all, and especially considering that reading the yasin has become a tradition of wiriddan in Lubuk Bayas Village.

\section{Conclusion}

The wiriddan tradition in Lubuk Bayas Village, Perbaungan District, Serdang Bedagai Regency, North Sumatra is a tradition that has long been practiced, and until now, it is still being implemented by the local community. This event is filled with reading (recite) the surah yasin together every Friday night and Friday at the residents' homes on a rotating system. One of the reasons for this is the rotating system because it eases the burden on the rest of the community in terms of providing dishes for the congregation. Apart from, of course, aiming to find virtue and blessings with routine recitation every Friday night and daytime, residents also read takhtim and takhlil intends to send the reading reward to the deceased who has left his family (in this case the host) to alleviate his suffering in the grave. But without realizing it, this event can be a means of strengthening the relationship between residents.

Wiriddan in this tradition, through the interview method, the writer can classify some of the social values that are considered very important by society and make them a motivation to continue to carry out the wiriddan tradition. As for the socio-religious values that are felt by the community, including the moment of gathering, the opportunity to give alms, mutual assistance, respect for teachers, and the existence of a forum for dialogue between residents, which can strengthen the ties of brotherhood, especially between neighbors

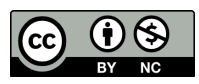

DOI: $10.19105 /$ karsa.v29i1.2345 


\section{Bibliography}

al-Baiḍāwī. Anwāar al-Tanzīl wa Asrār al-Ta'wìl. Beirut: Dār Iḥyā' alTurās̀ al-'Araby, 1418H/1998M.

al-Jawi, Muhammad Nawawi. Marāh Labīd. Beirut: Dar al-Kutub alIlmiyah,1997.

al-Maliki, Sayyid Muhammad Alwi. Keistimewaan-keistimewaan alQur'an. Yogyakarta: Mitra Pustaka, 2001.

al-Munawwar, Said Agil Husin. Al-Qur'an Membangun Tradisi Kesalehan Hakiki. Jakarta: Ciputat Press, 2003.

al-Qarḍāwī, Yusuf. Al-Halāl wa al-Harām fì al-Islām. Kairo: Maktabah Wahbah, 1993.

al-Qurțubī, Abū 'Abdillah Muḥammad Ibn Aḥmad. Al-Jami 'li Ahkām al-Qurān wa al-Mubayyin limā Tadammanah min al-Sunnah wa $\overline{A y}$ al-Furqān. Beirut: Mu'asasah al-Risalah.

al-Razi, Fakhr al-Din. Mafātih al-Ghaib. Beirut: Dar Ihya' at-Turats, 1999.

al-Ṭabarī, Ibn Jarīr. Jāmi ' al-Bayān 'an Ta'wīlì al-Qur'ān. Kairo: Dār Hajr, 1422H/2001M.

Amal, Taufik Adnan. Rekonstruksi Sejarah Al-Qur'an. Tanggerang, PT Pustaka Alvabet, 2013.

Arroisi Jarman, and Rahmat Ardi Nur Rifa Da'i. "Konsep Jiwa Perspektif Ibn Sina." ISLAMICA: Jurnal Studi Keislaman 13, no. 2 (Maret 2019): 256-278. https://doi.org/10.15642/islamica.2019. 13. 2.323-345.

Asad, Talal. "Thinking About Tradition, Religion, and Politics in Egypt Today." The University of Chicago Press Journals 42, no. 1 (Spring 2015): 166-214. https://www.journals.uchicago.edu/doi/ pdf/ $10.1086 / 683002$.

Bāqī, Fu'ād Abdul. Al-Mu 'jam al-Mufahras li al-Fāzil Qur'ānil Karīm. Kairo: Dār al-Kutub al-Misriyyah, 1364 H/1944M.

BPS-Statistics of Serdang Bedagai Regency. Kecamatan Perbaungan dalam Angka 2019. Deli Serdang: BPS Kabupaten Deli Serdang, 2019.

BPS-Statistics of Serdang Bedagai Regency. Serdang Bedagai Regency in Figures 2020. Serdang Bedagai: BPS Kabupaten Serdang Bedagai, 2020.

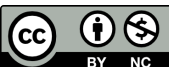

DOI: $10.19105 /$ karsa.v29i1.2345 
Chirzin, Muhammad. Buku Pintar Asbabul Nuzul: Mengerti Peristiwa dan Pesan Moral di Balik Ayat-ayat Suci Al-Qur'an. Jakarta: Zaman, 2011.

Denny, Federick M, and Rodney L. Taylor, ed. The Holy Book in Comparative Perspective. Colombia: University of South California Press, 1993.

Efendi, Nur, and Muhammad Fathurrohman. Studi Al-Qur'an: Memahami Wahyu Allah Secara Integral dan Komprehensif. Yogyakarta: Kalimedia, 2016.

Fairchild, Henry Pratt. Dictionary of Sociology. New York: Littlefield, Adams \& Company, 1977.

Ghazali, Abd. Moqsith. Argumen Pluralisme Agama; Membangun Toleransi Berbasis Al-Qur'an. Depok: KataKita, 2009.

Hafidz, Abdul, and Rusydi, "Konsep Dzikir dan Do'a Perspektif AlQur'an." Islamic Akademika: Jurnal Pendidikan dan Keislaman 6, no. 1 (2019): 54-77. https://doi.org/10.230303/staiattaqwa. v6i1.79.

Hamka. Tafsir al-Azhar Jilid 1. Jakarta: Gema Insani, 2015.

Hasan, Muhammad Zainul. "Resepsi Al-Qur'an sebagai Medium Penyembuhan dalam Tradisi Bejampi di Lombok." Jurnal Studi Ilmu-Ilmu al-Qur'an dan Hadis 21, no. 1 (2020): 133-152. https:// doi.org/10.14421/qh.2020.2101-07.

Kementrian Agama RI. Al-Qur'an dan Kebhinekaan. Jakarta: LPMA Badan Litbang dan Diklat Kemenag RI, 2011.

Kolip, Elly M. Setiadidan Usman. Pengantar sosiologi: Pemahaman Fakta dan Gejala Permasalahan Sosial; Teori Aplikasi, dan Pemecahannya. Jakarta: Kencana Prenada Media Group, 2011.

Misrawi, Zuhairi. Al-Qur'an Kitab Toleransi. Jakarta: Oasis, 2010.

Mukhibat. "Meneguhkan Kembali Budaya Pesantren dalam Merajut Lokalitas, Nasionalitas, dan Globalitas." Karsa: Journal of Social and Islamic Culture 23, no. 2 (2015): 177-192. https://doi.org/ 10.19105/karsa.v23i2.717.

Muslim, Romadoni. Do'a-Do'a Qur'ani. Jakarta: Intimedia Ciptanusantara, 2002.

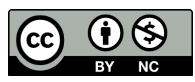

DOI: 10.19105/karsa.v29i1.2345 
Pusat Pembinaan dan Pengembangan Bahasa. Kamus Umum Bahasa Indonesia. Jakarta: PN. Balai Pustaka, 1976.

Qaththan, Manna' Khalil. Mabahits Fii 'Ulumil Quran. Translated by Mudzakir AS. Bogor: Litera Antar Nusa, 2009.

Rafiek, M. Ilmu Sosial \& Budaya Dasar. Yogyakarta: Aswaja Presindo. Rahmatullah. "Aspek Magic Surat al-Ikhlas dalam Kitab Khazinat alAsrar." QUHAS: Jurnal of Qur'an and Hadith Studies 7, no. 1 (2018): 42-60. https://doi.org/10.15408/quhas.v7i1.13389.

Saleh, KH. Qamaruddin, and H.A.A. Dahlan. Asbabun Nuzul Latar Belakang Historis Turunnya Ayat-ayat Al-Qur'an. Bandung: Diponegoro, 1986.

Setiawan, Muhammad Nur Kholis. al-Qur'an Kitab Sastra Terbesar. Yogyakarta: elsaq Press, 2006.

Shihab, M. Quraish. Tafsir Al-Mishbah: Pesan, Kesan dan Keserasian Al-Qur'an. Jakarta: Lentera Hati, 2002.

Soekanto, Soeryono. Sosiologi Suatu Pengantar. Jakarta : Rajawali Press, 1989.

Subaidi. "Pendidikan Karakter Berbasis Budaya Islami di MTs. Tahfidz Yanbu'ul Qur'an Menawan Kudus." Tadris: Jurnal Pendidikan Islam 14, no. 2 (2019): 189-200. https://doi.org/10.19105/ tjpi.v14i2.2737.

Suhadi. Kawin Lintas Agama Perspektif Kritik Nalar Islam. Yogyakarta: LkiS, 2006.

Surahman, Nasim. "10 Manfaat Baca Al-quran setiap Hari yang Luar Biasa.” Accessed Jun 9, 2021. https://jabar.kemenag.go.id/portal/ $\mathrm{read} / 10$-manfaat-baca-al-quran-setiap-hari-yang-luar-biasa.

Syamsuddin, Sahiron, ed. Metode Penelitian Living Qur'an dan Hadis. Yogyakarta: Teras, 2007.

Yusuf, Muhammad. "Pendidikan Karakter Berbasis Qurani dan Kearifan Lokal." Karsa: Journal of Social and Islamic Culture 22, no. 1 (2014): 53-66. https://doi.org/10.19105/karsa.v22i1.548.

Zaid, Nasr Hamid Abu. Tekstualitas Al-Qur'an: Kritik Terhadap Ulumul Qur'an, trans. Khoirun Nahdliyyin. Yogyakarta: LKIS, 2001.

Zen, Muhaimin. 2012. Al-Qur'an Seratus Persen Asli Sunni-Syi'ah Satu Kita Suci. Jakarta: Nur Al-Huda, 2012.

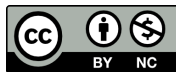

DOI: $10.19105 /$ karsa.v29i1.2345 